University of Nebraska - Lincoln

DigitalCommons@University of Nebraska - Lincoln

\title{
Geochemistry of Sulfate Minerals in High- and Low-Temperature Environments: A Tribute to Robert O. Rye
}

\author{
Robert R. Seal II \\ U.S. Geological Survey, 954 National Center, Reston, Virginia 20192, USA, rseal@usgs.gov \\ John L. Jambor \\ Leslie Research and Consulting, 316 Rosehill Wynd, Tsawwassen, British Columbia, V4M 3L9, Canada, \\ jljambor@aol.com \\ Charles N. Alpers \\ U.S. Geological Survey, 6000 J Street, Placer Hall, Sacramento, California 95819, USA, cnalpers@usgs.gov
}

Follow this and additional works at: https://digitalcommons.unl.edu/usgsstaffpub

Part of the Earth Sciences Commons

Seal, Robert R. II; Jambor, John L.; and Alpers, Charles N., "Geochemistry of Sulfate Minerals in High- and Low-Temperature Environments: A Tribute to Robert O. Rye" (2005). USGS Staff -- Published Research. 337.

https://digitalcommons.unl.edu/usgsstaffpub/337

This Article is brought to you for free and open access by the US Geological Survey at DigitalCommons@University of Nebraska - Lincoln. It has been accepted for inclusion in USGS Staff -- Published Research by an authorized administrator of DigitalCommons@University of Nebraska - Lincoln. 


\section{Geochemistry of sulfate minerals in high- and low-temperature environments: a tribute to Robert O. Rye}

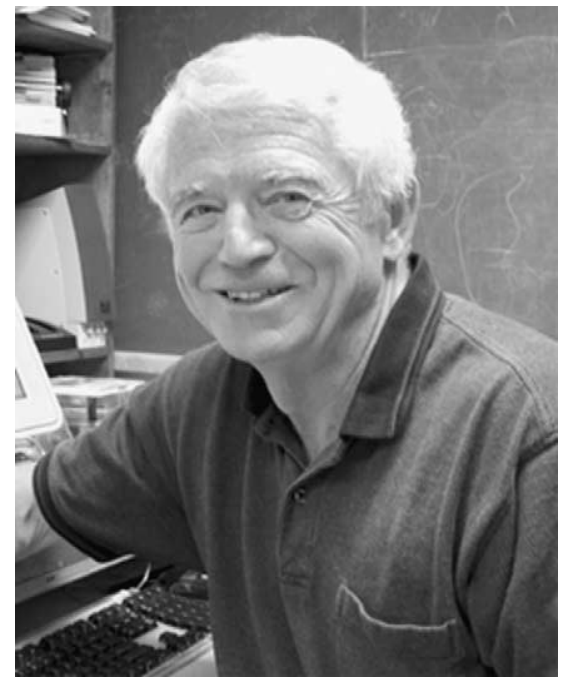

This special issue is a tribute to Robert O. Rye, known as "Bob" to most, in light of his highly productive and ongoing career. Almost all of the papers in this issue are derived from topical sessions on sulfate minerals in hydrothermal and low-temperature environments. The sessions, held at the 2000 Geological Society of America meeting in Reno, NV, and sponsored jointly by the Mineralogical Society of America, the Society of Economic Geologists and the Geochemical Society, included 29 oral and 9 poster presentations. The sessions complemented a short course on the crystallography, geochemistry and environmental significance of sulfate minerals, spon- sored by the Mineralogical Society of America and the Geochemical Society, which immediately preceded the meeting (Alpers et al., 2000). The 23 papers in this special issue typify the breadth of Bob Rye's research in this important area of geochemistry.

Bob's undergraduate degree, with a combined major in geology and mathematics, was received in 1960 from Occidental College (Los Angeles, CA). Bob then moved on to Princeton where he worked with Dick Holland on the geochemistry of the $\mathrm{Pb}-\mathrm{Zn}$ ores of Providencia, Mexico. In the course of his PhD research, which he completed in 1965, Bob began his long associations with both the U.S. Geological Survey (USGS) and the field of stable-isotope geochemistry by conducting a significant part of his research in Irving Friedman's laboratory in Denver, CO. After completing his dissertation, he continued with the USGS and soon began establishing his stateof-the-art stable-isotope laboratory. The development of the laboratory has remained an ongoing process because of Bob's insistence on remaining on the cutting edge of stable-isotope geochemistry research, and because of the numerous technological advancements in the field over the past 40 years. During these four decades, Bob has received numerous awards. He has received the U.S. Department of Interior's Meritorious Service Award, and its highest honor, the Distinguished Service Award, in recognition of his scientific accomplishments and contributions to the organization. In 1973, he received the Society of Economic Geologists' Lindgren Award given to an outstanding young scientist. Bob was the first 
Lindgren recipient to honor the implied commitment to excellence in science and earn the society's Silver Medal for mid-career achievement in 1991.

The hallmarks of Bob's career have been, and continue to be, his innovation, thoroughness, a keen sense of the state of the art, which enables him to key into the areas for most fruitful research, and above all, his generosity. At the time of his dissertation research, the field of stable-isotope geochemistry as applied to mineral deposits was dominated by several landmark studies using single isotopic systems, such as oxygen or sulfur. Bob had the foresight to apply multiple isotopic systems (oxygen, hydrogen and carbon) to the study of ore deposits at Providencia (Rye, 1966). Today, it is routine to apply multiple isotopic systems to the study of hydrothermal systems and the approach is ingrained in our geochemical subconscious; it is fair to say that it is in part to Bob Rye's efforts that we owe this imprint on our scientific psyche. When Bob applied sulfur isotopes to the study of Providencia, he did it in the context of insightful evaluation of the robustness of the two most useful geothermometers for the study of hydrothermal ore deposits (then and now) - fluid inclusions and stableisotope fractionation among coexisting minerals (Rye, 1974; Czamanske and Rye, 1974).

Bob's early work at Providencia began his careerlong quest to understand the role of magmas in the formation of ore deposits. His early appreciation of the role of climatic setting on the isotopic signature of meteoric waters led him, with several colleagues, through a series of definitive studies that better defined the relative roles of magmatic and meteoric water, and their mixing in the formation of hydrothermal ore deposits (Ohmoto and Rye, 1970; Rye and Sawkins, 1974; Landis and Rye, 1974). Bob's interest in magma-related ore deposits also resulted in classic papers on volcanogenic massive sulfide deposits (Ohmoto and Rye, 1974; Rye et al., 1984), graniterelated Sn-W deposits (Kelly and Rye, 1979) and epithermal precious-metal deposits (Bethke and Rye, 1979; Ebert and Rye, 1997).

Bob's work at Providencia early on established a keen sense of the crucial importance of a time-space framework in tracing the evolution of hydrothermal ore-forming systems - a principle he has embraced throughout his career. Despite having made significant advances in the understanding of the evolution of hydrothermal ore deposits, their complex paragenetic relationships gave to Bob the same feelings of frustration that had plagued economic geologists for decades. The multiple generations of wallrock alteration, the crosscutting relationships of alteration assemblages and veins, the zonation within the veins and the intermittent formation of various mineral groups (for example, silicates, sulfides, sulfates, carbonates and native metals) during hydrothermal activity made it almost impossible to anchor stable isotopic interpretations to a single point in geological time. Oxygen isotopic data would commonly come from hydrothermal quartz or carbonate of a different paragenetic stage than the mica used for hydrogen isotopic data, which likewise was from a different stage than the sulfide or sulfate mineral used for sulfur isotopic data. Bob recognized of the potential of the sulfate mineral alunite $\left[\mathrm{KAl}_{3}\left(\mathrm{SO}_{4}\right)_{2}(\mathrm{OH})_{6}\right]$, a minor but common mineral in hydrothermal ore deposits in which acid-sulfate alteration is associated with magmatic activity. He realized that alunite offers an unparalleled opportunity to gain insights into the sulfur, oxygen and hydrogen isotopic evolution of an ore deposit because alunite can be anchored to specific points in time in the deposit's evolution. The presence of potassium in the structure made it possible for those points in time to be dated using $\mathrm{K}-$ $\mathrm{Ar}$ (and more recently ${ }^{40} \mathrm{Ar}-{ }^{39} \mathrm{Ar}$ ) geochronological techniques. Initially, it was a problem that little was known about isotopic exchange between alunite and water, either with regard to fractionation factors or kinetics. This challenge was met with a series of thorough laboratory and field studies on the stable isotope systematics of alunite and the related mineral jarosite $\left[\mathrm{KFe}_{3}\left(\mathrm{SO}_{4}\right)_{2}(\mathrm{OH})_{6}\right]$. Bob and his colleagues investigated equilibrium and kinetic controls on isotopic fractionation associated with these minerals (Stoffregen et al., 1994a,b; Rye and Stoffregen, 1995), developed techniques for their isotopic analysis (Wasserman et al., 1992), and applied this knowledge to a variety of high- and low-temperature acid-sulfate systems (Rye et al., 1989, 1991, 1992; Rye, 1993; Rye and Alpers, 1997). Through these efforts, alunite and jarosite were developed into powerful and unique sensors of ancient hydrothermal and supergene environments. The choice of this volume on the geochemistry of sulfate minerals to honor Bob is highly appropriate. 
The spectrum of Bob's interests in the application of stable isotopes to geochemical problems goes well beyond magma-related ore deposits. He has investigated nearly every major mineral-deposit type. With stable isotopes, he has also made major contributions to the fields of igneous and metamorphic petrology, geothermal resources, environmental geochemistry, climate change, geomorphology and natural hazards. With a style that is uniquely Bob's, he manages elegantly to combine several of these fields, as demonstrated by his interest in the link between climate and ore-forming processes, much of which has focused on his long-standing interest in the Creede hydrothermal system in southwestern Colorado, USA (Bethke and Rye, 1979; Rye et al., 2000a,b) and also in northern Nevada, USA (Ebert and Rye, 1997). In the last several years, he has begun to explore the application of stable isotopes to biological problems, such as understanding food-web relationships involving fish, birds and bears, and determining the migratory paths of birds.

Generosity is another striking characteristic of Bob. His lab has served as a scientific "birthing ground" and "nursery" for many of the modern ideas of hydrothermal geochemistry and many of its practitioners. Bob's lab has always been a place of amazing activity and incredible excitement of discovery. It has always hosted a steady stream of guest scientists, including graduate students, post docs, academics, USGS colleagues and visiting researchers from around the world, all of whom get swept away in stimulating discussions. The time, energy and dedication that Bob brings to these interactions are remarkable, whether it is explaining fundamental aspects of stable-isotope geochemistry to the newcomer, discussing advanced topics with experienced researchers or troubleshooting analytical challenges. The benefits to his guest researchers and colleagues, and therefore, to science, are immeasurable.

The 23 papers included in this special issue cover the spectrum of Bob Rye's scientific contributions to understanding sulfate minerals in a variety of environments. Remarkably, 10 of the papers are either authored or co-authored by Bob-a testament to the breadth and lasting impact of his research in this area of geochemistry. The general organization of this special issue is from high temperature to low temperature. Appropriately, the first paper is by Bob-a review of the stable-isotope geochemistry of sulfate minerals in igneous and related hydrothermal environments that begins with consideration of processes operating at magmatic temperatures, followed by those at hydrothermal conditions, and then those at near-ambient conditions. The other papers in the special issue that focus on hydrothermal processes collectively begin at magmatic conditions and continue down through the magmatic-hydrothermal transition and through epithermal conditions. Also reported are investigations of various aspects of supergene processes imprinted upon earlier hydrothermal signatures, including the modern environmental geochemistry of ore deposits and mine wastes and other low-temperature environments. Several of the papers address the foundations of the fields of stable isotope geochemistry, fluid-inclusion gas chemistry, mineral chemistry and isotopic geochronologyall areas of Bob's interests. Furthermore, the contributions span the spectrum from dominantly fieldbased to dominantly laboratory-based studies, including of course Bob's forte, integrated studies and the contributions vary from the theoretical to the experimental to the applied in scope.

With this special issue, we congratulate Bob Rye on more than 40 years of major scientific contributions and we look forward to many more. He is arguably the father of modern stable-isotope geochemistry of ore deposits, both from the analytical and interpretative perspectives. Bob has been the mentor for and colleague of many of the current scientific leaders in the fields of economic geology and stable-isotope geochemistry. His scientific contributions to the field of isotope geochemistry, particularly as it relates to ore deposits, have been enormous.

\section{References}

Alpers, C.N., Jambor, J.L., Nordstrom, D.K. (Eds.), 2000. Sulfate Minerals - Crystallography, Geochemistry, and Environmental Significance, Rev. Mineral. Geochem., vol. 40, 608 pp.

Bethke, P.B., Rye, R.O., 1979. Environment of ore deposition in the Creede Mining District, San Juan Mountains, Colorado: Part IV. Source of fluids from oxygen, hydrogen and carbon isotope studies. Econ. Geol. 74, 1832-1851.

Czamanske, G.K., Rye, R.O., 1974. Experimentally determined sulfur isotope fractionation between sphalerite and galena in the temperature range 600 to $275{ }^{\circ} \mathrm{C}$. Econ. Geol. 69, $17-25$. 
Ebert, S.W., Rye, R.O., 1997. Secondary precious-metal enrichment by steam-heated fluids in the Crofoot-Lewis hot spring goldsilver deposit and relation to paleoclimate. Econ. Geol. 92, $578-600$.

Kelly, W.C., Rye, R.O., 1979. Fluid inclusion and stable isotope studies of the Panasqueira tin-tungsten deposit, Portugal. Econ. Geol. 74, 1721-1822.

Landis, G.P., Rye, R.O., 1974. Geologic, fluid inclusion and stable isotope studies of the Pasto Bueno tungsten base metal deposit, northern Peru. Econ. Geol. 69, 1025-1059.

Ohmoto, H., Rye, R.O., 1970. The Bluebell Mine, British Columbia. I: mineralogy, paragenesis, fluid inclusions and the isotopes of hydrogen, oxygen and carbon. Econ. Geol. 65, 417-437.

Ohmoto, H., Rye, R.O., 1974. Hydrogen and oxygen isotope composition of water in fluid inclusion in the Kuroko deposit, Japan. Econ. Geol. 69, 947-953.

Rye, R.O., 1966. Carbon, hydrogen and oxygen isotopic composition of the hydrothermal fluids responsible for the $\mathrm{Pb}-\mathrm{Zn}$ deposits at Providencia, Zacatecas, Mexico. Econ. Geol. 61, $1399-1427$.

Rye, R.O., 1974. A comparison of sphalerite-galena sulfur isotope temperatures with filling temperatures of fluid inclusions. Econ. Geol. 69, 26-32.

Rye, R.O., 1993. The evolution of magmatic fluids in the epithermal environment: the stable isotope perspective: SEG distinguished lecture. Econ. Geol. 88, 733-753.

Rye, R.O., Alpers, C.N., 1997. The stable isotope geochemistry of jarosite. U. S. Geol. Surv. Open-File Rep. 97-88, $28 \mathrm{pp}$.

Rye, R.O., Sawkins, F.J., 1974. Fluid inclusions and stable isotope studies on the Casapalca $\mathrm{Ag}-\mathrm{Pb}-\mathrm{Zn}-\mathrm{Cu}$ deposit, Central Andes, Peru. Econ. Geol. 69, 181-205.

Rye, R.O., Stoffregen, R.E., 1995. Jarosite-water oxygen and hydrogen isotope fractionations: preliminary experimental data. Econ. Geol. 90, 2336-2342.

Rye, R.O., Roberts, R.J., Snyder, W.S., Lahusen, L.A., Motica, J.E., 1984. Textural and sulfur isotopic studies of the Big Mike cupriferous volcanogenic massive sulfide deposit, Pershing County, Nevada. Econ. Geol. 79, 124-140.

Rye, R.O., Bethke, P.M., Wasserman, M.D., 1989. Diverse origins of alunite and acid-sulfate alteration: stable isotope systematics. U. S. Geol. Surv. Open-File Rep. 89-5, 33.
Rye, R.O., Bethke, P.M., Wasserman, M.D., 1991. The stable isotope geochemistry of alunite and vein-forming alunite. U. S. Geol. Surv. Open-File Rep. 91-257, 59 pp.

Rye, R.O., Bethke, P.M., Wasserman, M.D., 1992. The stable isotope geochemistry of alunite. Econ. Geol. 87, 225-262.

Rye, R.O., Bethke, P.M., Finkelstein, D.B., 2000a. Stable isotope evolution and paleolimnology of Ancient Lake Creede. Spec. Pap. Geol. Soc. Am. 346, 233-266.

Rye, R.O., Bethke, P.M., Lanphere, M.A., Steven, T.A., 2000 b. Neogene geomorphic and climatic evolution of the central San Juan Mountains, $\mathrm{CO}: \mathrm{K} / \mathrm{Ar}$ age and stable isotope data on supergene alunite and jarosite from the Creede mining district. Spec. Pap. Geol. Soc. Am. 346, 95-104.

Stoffregen, R.E., Rye, R.O., Wasserman, M.D., 1994a. Experimental studies of alunite. I: ${ }^{18} \mathrm{O}$ and $\mathrm{D}$ fractionation factors between alunite and water at $250-450{ }^{\circ} \mathrm{C}$. Geochim. Cosmochim. Acta 58, 903-916.

Stoffregen, R.E., Rye, R.O., Wasserman, M.D., 1994b. Experimental studies of alunite II. Rates of alunite-water alkali and isotope exchange. Geochim. Cosmochim. Acta 58, 917-929.

Wasserman, M.D., Rye, R.O., Bethke, P.M., Arribas, A., 1992. Methods for separation and total stable isotope analyses of alunite. U. S. Geol. Surv. Open-File Rep. 92-9, 20 pp.

Robert R. Seal II*

U.S. Geological Survey, 954 National Center, Reston, Virginia 20192, USA

E-mail address:rseal@usgs.gov.

*Corresponding author. Tel.: +1 703648 6290; fax: +17036486383 .

John L. Jambor

Leslie Research and Consulting, 316 Rosehill Wynd, Tsawwassen, British Columbia, V4M 3L9, Canada E-mail address: jljambor@aol.com.

Charles N. Alpers U.S. Geological Survey, 6000 J Street, Placer Hall, Sacramento, California 95819, USA E-mail address: cnalpers@usgs.gov. 